\title{
REPRODUCTIVE BIOLOGY OF THE TIGRIS SCRAPER, CAPOETA UMBLA (HECKEL, 1843) POPULATION LIVING IN SOLHAN CREEK OF MURAT RIVER (BINGÖL, TURKEY)
}

\author{
Zeliha ERDOĞAN *, Hatice TORCU KOÇ ** and Fatih ÖZDEMIR *** \\ * University of Balikesir, Department of Biology, Faculty of Science and Arts, Cağış Campus, 10145, \\ Balikesir, Turkey, zaka@balikesir.edu.tr, ORCID: 0000-0002-5725-4402 \\ ** University of Balikesir, Department of Biology, Faculty of Science and Arts, Cağış Campus, 10145, \\ Balikesir, Turkey, htorcu@balikesir.edu.tr, ORCID: 0000-0003-0678-1509 \\ *** University of Balikesir, Department of Biology, Faculty of Science and Arts, Cağış Campus, 10145, \\ Balikesir, Turkey, fozdemir1@windowslive.com, ORCID: 0000-0002-3257-6210
}

DOI: $10.2478 /$ trser-2021-0013

KEYWORDS: Capoeta umbla, reproductive cycle, maturity, fecundity, Solhan Creek.

\section{ABSTRACT}

We studied the reproductive traits in 23 of 190 individuals of Capoeta umbla caught monthly in the Solhan Creek of the Murat River between April 2017 and March 2018. The sex ratio (F:M) was found to be 1:1.11. The macroscopic examination of the gonads and gonadosomatic index indicated that the reproductive period lasted from May to August with peak activity in May. The fecundity ranged from 2,000 to 9,000 oocytes, and it correlated with the total length and body weight. This work represents the first attempt to investigate the reproductive traits of the Capoeta umbla population in the Solhan Creek. The results provide information on the reproductive biology and contribute to the conservation of the fish population and its sustainable management.

RÉSUMÉ: Biologie reproductive du grattoir du Capoeta umbla (Heckel, 1843) population vivant à Solhan bras de mer de la rivière Murat (Bingöl, Turquie).

Sur 190 individus de Capoeta umbla capturés chaque mois dans le ruisseau Solhan et la rivière Murat entre avril 2017 et mars 2018, les aspects reproductifs de 23 individus ont été étudiés. Le sex-ratio (F:M) était de 1:1,11. L'examen macroscopique des gonades et de l'indice gonado-somatique ont indiqué que la période de reproduction dure de mai à août avec un pic d'activité en mai. Les estimations de la fécondité variaient de 2.000 à 9.000 ovocytes, et elles ont été considérées comme corrélées avec la longueur totale et le poids corporel. Ce travail représente la première tentative d'étudier les aspects reproductifs de la population de Capoeta umbla à Solhan Creek. Les résultats fournissent des informations fondamentales sur la biologie delareproduction etcontribuentàla conservationdelapopulation depoissons età sa gestiondurable.

REZUMAT: Biologia reproductivă a populației de Capoeta umbla (Heckel, 1843) care trăiește în Pârâul Solhan al Râului Murat (Bingöl, Turcia).

Din 190 de indivizi de Capoeta umbla capturați lunar în pârâul Solhan al râului Murat, între aprilie 2017 şi martie 2018, au fost studiate aspectele reproductive la 23 dintre ei. Raportul pe sexe (F:M) a fost găsit ca fiind 1:1,11. Examinarea macroscopică a gonadelor și a indicelui gonado-somatic a indicat faptul că perioada de reproducere durează din mai până în august, cu activitate maximă în luna mai. În ceea ce priveşte fecunditatea, numărul ovocitelor a variat între 2.000 și 9.000 , și s-a văzut că este corelat cu lungimea totală și greutatea corporală. Această lucrare reprezintă prima încercare de a investiga aspectele reproductive ale populației de Capoeta umbla din Pârâul Solhan. Rezultatele oferă informații fundamentale despre biologia reproducerii și contribuie la conservarea populației de pești și la gestionarea durabilă a acesteia. 


\section{INTRODUCTION}

Fish around the world are significantly impacted by direct or indirect human impact, and they have a decreasing ecological trend due to this impact (Sheridan, 2008; Trichkova et al., 2009; Jeeva et al., 2011; Khoshnood, 2014; Sosai, 2015; Gebrekiros, 2016; Kar and Khynriam, 2020; Radkhah and Eagderi, 2020; Reynaldo de la Cruz, 2020; Rios, 2021; Su et al., 2021).

Studies on the reproductive biology of fish are important to plan better conservation and management strategies of fishery resources (Grandcourt, 2009; Muchlisin et al., 2010). Reproductive biological traits play a basic role in fishery management (Miller, 1984; Komalefe and Arawomo, 2007). Knowledge of the length of the fish at first maturity and spawning season is essential for local authorities to set the suitable fish length and time for fishing (Dinh, 2018). Fecundity is among the most important aspects of fish biology, which must be understood to explain the variation in the population level as well as to make efforts to increase the fish harvest (Das et al., 1989). Determining the fecundity and the development of sexual maturity in fish is fundamental to fishery science (Brown et al., 2003). In fish biology, the analysis of life history traits related to reproduction has mainly focused on females, in part because the offspring production is limited to a greater degree by the egg production, rather than by the sperm production (Helfmann et al., 1997; Murua and Saborido-Rey, 2003).

The genus Capoeta, Cyprinidae, is distributed in southern China, northern India, Turkmenistan, Lake Aral, the Middle East, and Anatolia (Bănărescu, 1999). Its representatives inhabit mainly fast flowing streams and rivers and are also found in lakes and springs (Turan et al., 2006). Freyhof (2014) and Esmaeili et al. (2016) reported the presence of Capoeta umbla in Iran (Tigris River basin), Iraq, Syria, and Turkey (Asian part) and listed it in the Least Concern (LC) category. Capoeta umbla is called black fish, Zeruke, sarı balık, or Siraz (Turkish) (Türkmen et al., 2002; Çiçek et al., 2016). Some investigations regarding various biological traits of Capoeta umbla have been carried out in Tercan Dam Lake and Tuzla River (Gül et al., 1996), Hazar Lake (Yüce and Şen, 2003), and the Ceyhan Dam Lake (Kara et al., 2010).

Capoeta umbla is the most commercially valued fish for the local people around the Murat River. Since the current work has been carried out on Capoeta umbla in the Murat River and its creeks, some general data regarding the reproduction of this species in the Solhan Creek are presented here. Accordingly, this study aims to enrich the knowledge on the reproductive traits of Capoeta umbla, such as the sex ratio, reproductive season, fecundity, and its relationship with total length and total weight, which may be used for fishery management.

\section{MATERIAL AND METHODS}

The Solhan Creek is one of the important branches feeding the Murat River and is located in upper Firat of Eastern Anatolia (Kılıç, 2015). This creek is 39 kilometers from Bingöl City.

For each fish, the total length (TL) was approximated to the nearest $\mathrm{mm}$ and the total weight (TW) to $0.1 \mathrm{~g}$. The sex (male, female) and gonads were analysed macroscopically and the gonad weight $(\mathrm{GW})$ was approximated to $0.01 \mathrm{~g}$. The maturity stages of the gonads were determined with reference to the universal scale, considering five stages in accordance with Holden and Raitt (1974) (Tab. 1). Fish with gonads at stage greater than or equal to three were considered mature (Fontana, 1979). 
Table 1: A five-point maturity scale for partial spawners.

\begin{tabular}{|c|c|l|}
\hline Stage & State & \multicolumn{1}{c|}{ Description } \\
\hline I & Immature & $\begin{array}{l}\text { Ovary about 1/3 length of body cavity. } \\
\text { Ovaries pinkish, translucent. } \\
\text { Eggs not visible to naked eye. }\end{array}$ \\
\hline II & Maturing & $\begin{array}{l}\text { Ovary about 1/2 length of body cavity. } \\
\text { Ovary pinkish, translucent. } \\
\text { Eggs not visible to naked eye. }\end{array}$ \\
\hline III & Ripening & $\begin{array}{l}\text { Ovary and testis are about 2/3 length of body cavity. } \\
\text { Ovary pinkish-yellow colour with granular appearance. } \\
\text { No transparent or translucent eggs visible. }\end{array}$ \\
\hline IV & Ripe & $\begin{array}{l}\text { Ovary from 2/3 to full length of body cavity. } \\
\text { Ovary orange-pink in colour with conspicuous superficial blood vessels. } \\
\text { Large transparent, ripe eggs visible. }\end{array}$ \\
\hline V & Spent & $\begin{array}{l}\text { Ovary shrunken to about 1/2 length of body cavity. } \\
\text { Walls loose. } \\
\text { Ovary may contain remnants of disintegrating opaque and ripe eggs, } \\
\text { darkened or translucent. }\end{array}$ \\
\hline
\end{tabular}

The sex ratio is defined as the proportion of each sex, determined by macroscopic observation of gonads in a given population (Avşar, 2016). The principal hypothesis supposes that there is equal sex ratio. This was evaluated with a chi-square test $\left(\chi^{2}\right)$ (Sümbüloğlu and Sümbüloğlu, 2019).

To quantify the changes in the gonad weight during the annual sexual cycle and to determine the spawning season, we calculated the gonad-somatic index (GSI) for 190 specimens (90 females and 100 males) by the following formula: GSI = (GW/SW) x 100, GW: gonad weight (g), SW: somatic weight (g) (body weight minus gonad weight) (Avşar, 2016).

The gravimetric or weight method has been successfully used by Doha and Hye (1970), Bagenal and Braum (1978), Shafi et al. (1978), Dewan and Doha (1979), Sarker et al. (2002). It offers the best possibility of minimizing errors owing to its simple and easy sampling techniques. This method has been used for its greater efficacy compared to the other methods (Bitty Blanchard et al., 2003). The gravimetric method was applied as follows: before estimating the fecundity, a sample of $0.1 \mathrm{~g}$ was taken separately from the anterior, posterior, and middle region of the lobe of each ovary and weighted.

The fecundity (F1) was estimated by using the following equation (Yeldan and Avşar, 2000):

$$
\begin{aligned}
& \text { No. of eggs in sub sample } \times \text { Gonad weight } \\
& \text { Fecundity }(F 1)=\text { - }
\end{aligned}
$$

Then, by taking the mean number of three sub-sample fecundities (F1, F2, and F3), the individual fecundity for each female fish was calculated by the following equation:

$$
\text { Fecundity }(\mathrm{Fe})=\frac{\mathrm{F} 1+\mathrm{F} 2+\mathrm{F} 3}{\mathrm{---}}
$$


The total length and body weight of fish were estimated to establish a mathematical relationship with fecundity: $F=a . L^{b}$, where $F=$ fecundity (dependent variable), $L=$ total fish length $(\mathrm{cm})$; and the regression equation: $\mathrm{F}=\mathrm{a}+\mathrm{b}(\mathrm{W}-\mathrm{GW})$, where $\mathrm{F}=$ Fecundity, $\mathrm{GW}=$ gonad weight $(\mathrm{g}), \mathrm{W}=$ total fish weight $(\mathrm{g}), \mathrm{a}=$ regression constant, and $\mathrm{b}=$ regression coefficient (Bagenal and Braum, 1987; Avşar, 2016).

\section{RESULTS AND DISCUSSION}

A total of 190 specimens were examined in our study. The macroscopic study of gonads showed that the sample consisted of 90 females and 100 males (Figs. 1a-b).

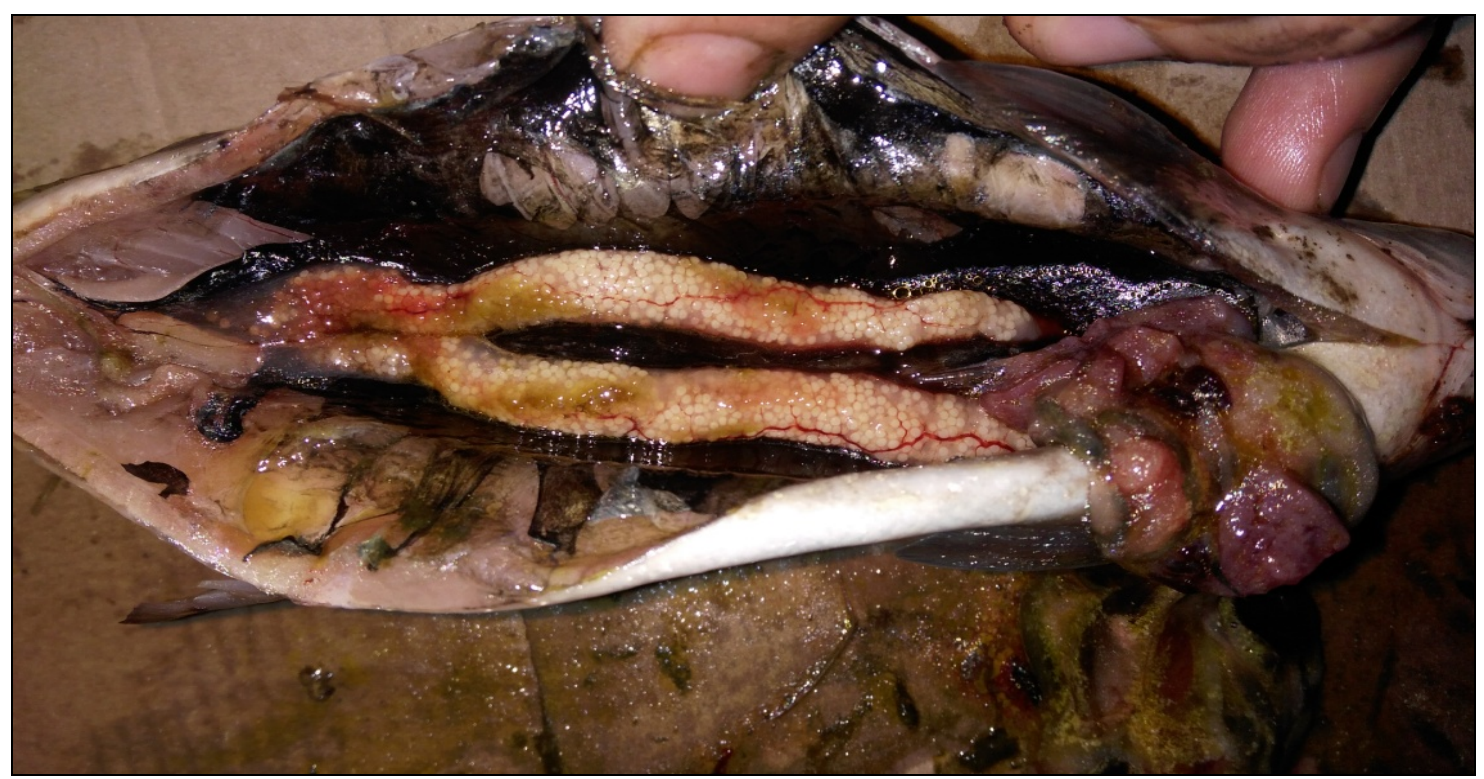

Figure 1a: Female gonads.

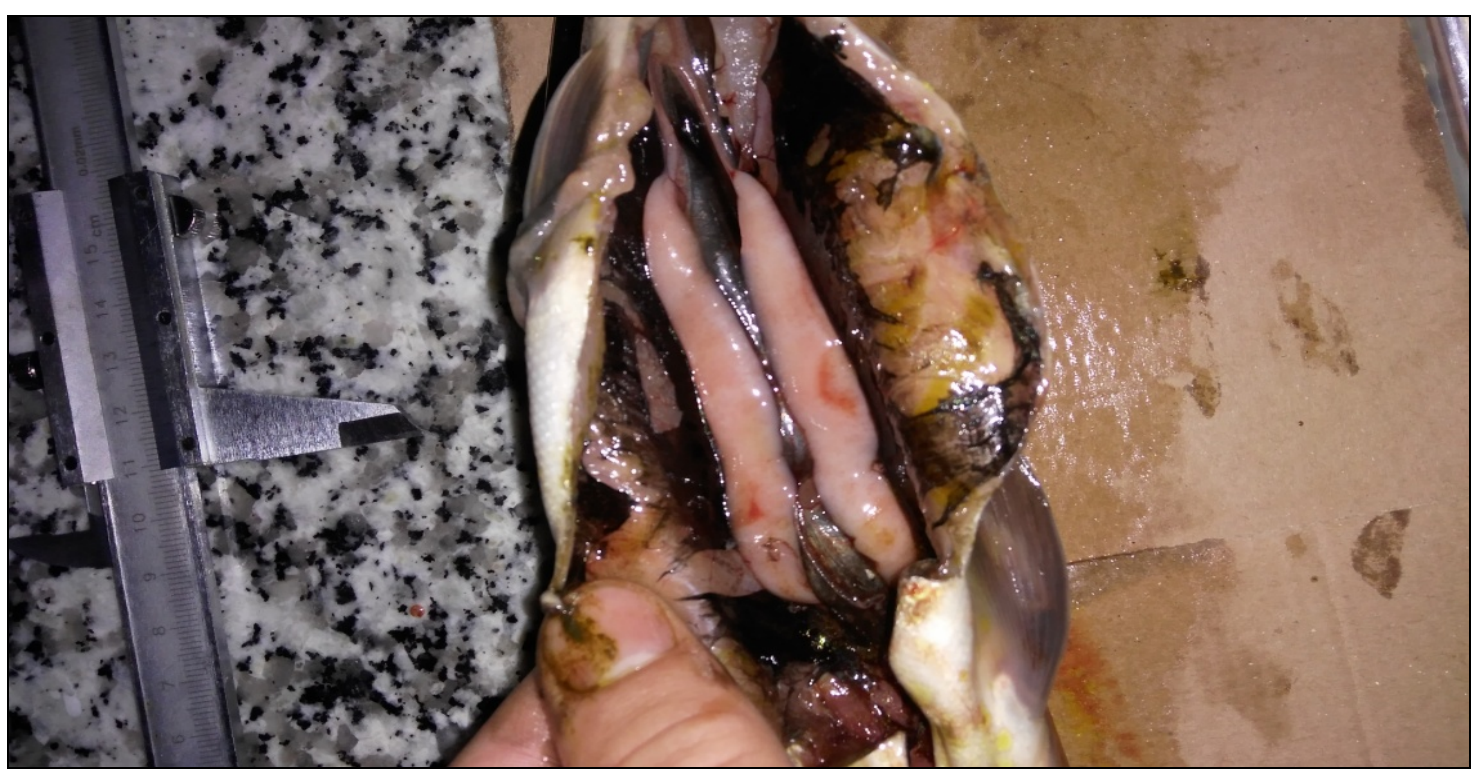

Figure 1b: Male gonads. 
The gonado-somatic index indicated that the reproductive period lasted from May to August with peak activity in May. The highest average values of GSI were found in May, 11.57 and 11.74 for male and female respectively, while the lowest average values were in July (1.93), respectively (Fig. 2).

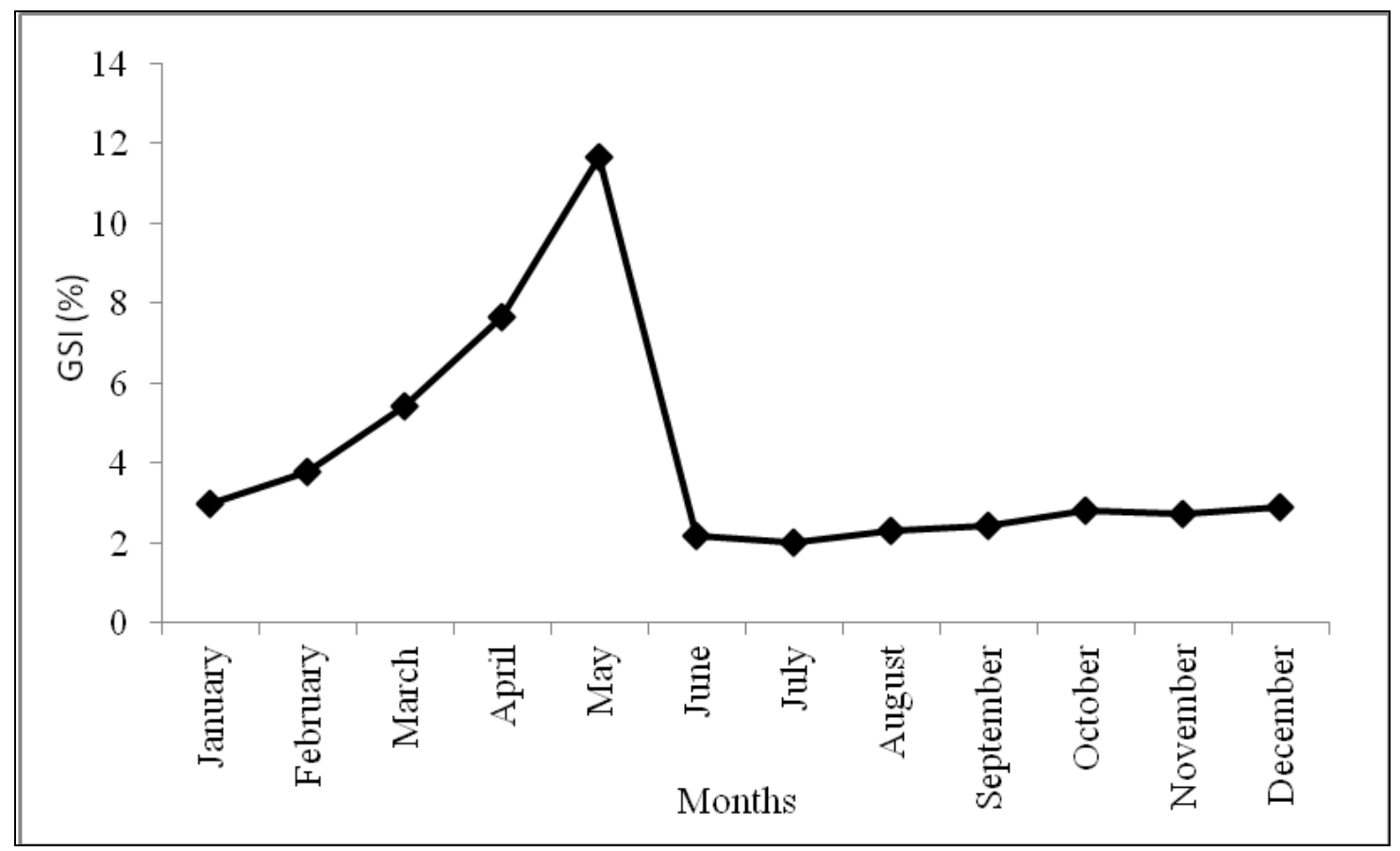

Figure 2: Gonadosomatic index of Capoeta umbla

in the Solhan Creek in the Murat River according to months.

The fecundity of 169 mature female fish was estimated within the range from 2,000 to 9,000 oocytes for the corresponding total length and body weight of the fish: from $19.5 \mathrm{~cm}$ and $76.00 \mathrm{~g}$ to $32.2 \mathrm{~cm}$ and $333 \mathrm{~g}$, respectively.

The exponential relationship between the fecundity and total length was expressed as $\mathrm{F}=1.421 \times \mathrm{TL}^{2.527}\left(\mathrm{R}^{2}=0.463\right)$ (Figs. 3a-b).

The diagram obtained from the fecundity and body weight showed a positive linear relationship that was expressed as $F=2107 T W+1858\left(R^{2}=0.390\right)$. 


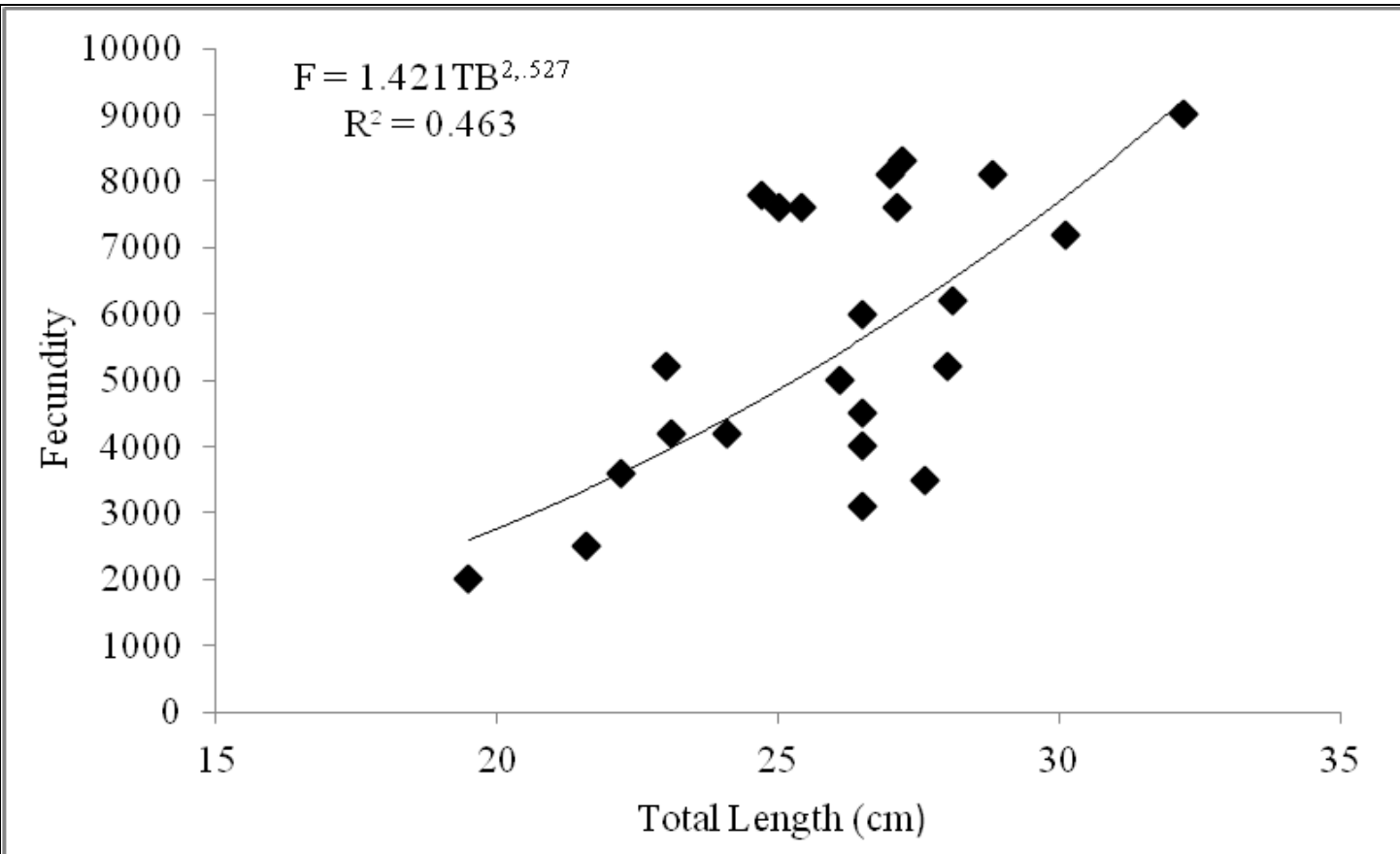

Figure 3a: Relationship between fecundity and total length of Capoeta umbla in the Solhan Creek of the Murat River.

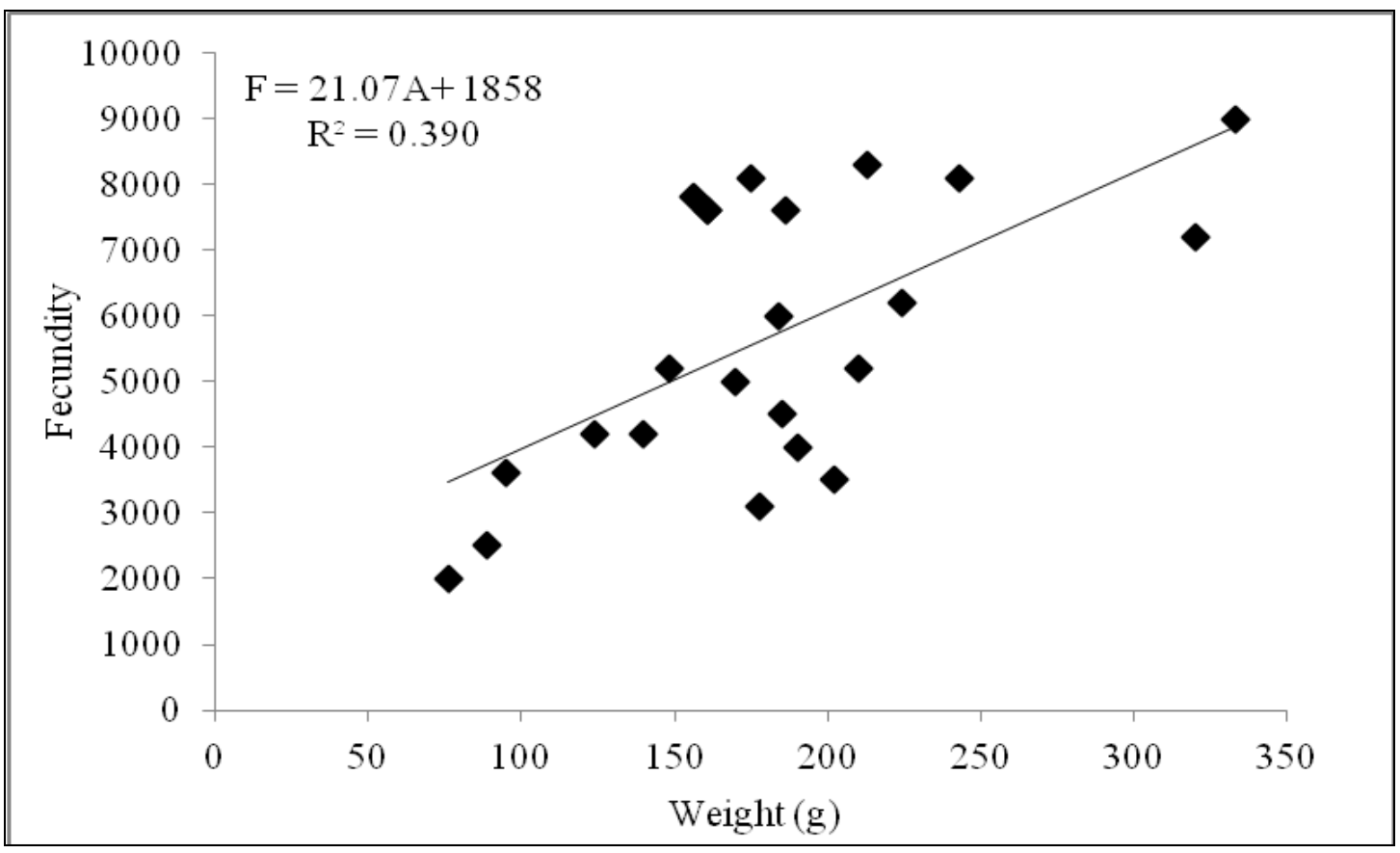

Figure 3b. Relationship between fecundity and weight of Capoeta umbla in the Solhan Creek of the Murat River. 
It was found that the absolute fecundity was slightly correlated with the total body length and the results revealed that the fecundity increased as the female fish grew in dimension.

A total of 190 specimens of Capoeta umbla were collected during the studied period, comprised of $52.63 \%$ males and $47.37 \%$ females. The sex ratio (F:M) was $1: 1.11$ and significantly different from 1:1 (t-test, $\mathrm{P}>0.05$ ). This agrees with some researchers who studied other Capoeta umbla populations and pointed out that the annual sex ratio has dominance of males (Tab. 2). Nikolsky (1980) indicated different sexual dispersions of the same species in various populations. It is well known that the sex ratio in most species is close to one, but it may vary from species to species, from one population to another in the same species, and from year to year in the same population.

Table 2: Sex ratio of Capoeta umbla populations in the relevant literature.

\begin{tabular}{|c|c|c|c|c|}
\hline Researcher & Locality & Female\% & Male\% & Sex Ratio \\
\hline Yüksel (2002) & Hazar Lake & 52.48 & 47.52 & $\mathrm{D}: \mathrm{E}=1.10: 1$ \\
\hline Y1lmaz et al. (2003) & Firat River & 48.51 & 51.49 & $\mathrm{D}: \mathrm{E}=0.94: 1$ \\
\hline \multirow{2}{*}{ Güneş (2007) } & Tuzla Stream & 47.56 & 52.44 & $\mathrm{D}: \mathrm{E}=0.91: 1$ \\
\hline & Tercan Dam Lake & 51.08 & 48.92 & $\mathrm{D}: \mathrm{E}=1.04: 1$ \\
\hline \multirow{2}{*}{ Çoban and Şen (2011) } & Hazar Lake & 46.97 & 53.03 & $\mathrm{D}: \mathrm{E}=0.72: 1$ \\
\hline & Keban Dam Lake & 42.11 & 57.89 & $\mathrm{D}: \mathrm{E}=0.88: 1$ \\
\hline Çoban et al. (2013) & Hazar Lake & 65.09 & 34.91 & $\mathrm{D}: \mathrm{E}=1.87: 1$ \\
\hline Gündüz et al. (2015) & Uzunçayır Dam Lake & 35.42 & 64.58 & $\mathrm{D}: \mathrm{E}=0.55: 1$ \\
\hline Çiçek et al. (2016) & Dicle Nehri & 67 & 15 & $\mathrm{D}: \mathrm{E}=4.47: 1$ \\
\hline Eroğlu et al. (2018) & Özlüce Dam Lake & 59.31 & 40.69 & $\mathrm{D}: \mathrm{E}=1.46: 1$ \\
\hline This study & Murat River & 47.64 & 52.36 & $\mathrm{D}: \mathrm{E}=1: 1.11$ \\
\hline
\end{tabular}

The analysis of the GSI index and data of the maturity stages suggests that the main spawning season is summer, beginning in May and lasting till July (Fig. 1). The spawning seasons of Capoeta umbla were compared to the relevant studies (Tab. 3).

Table 3: Spawning seasons ( $\mathrm{J}$ - D, January to December) of Capoeta umbla according to previous studies.

\begin{tabular}{|l|l|l|l|l|l|l|l|}
\hline Researcher & Locality & J & F & M A \\
\hline Özdemir (1982) & Hazar Lake & &
\end{tabular}


The spawning season exhibited a different pattern in other areas (Tab. 3). It may be said that the starting and finishing time of reproduction might include different months because of the ecological and climatic conditions. The spawning cycle is closely related to temperature. The spawning periods of fish vary also with respect to such ecological differences as stagnant or running water, as well as altitude, temperature, and quality of food. (Nikolsky, 1980)

Data on fish fecundity are much less available than data on maturity and sex ratio (Tomkiewicz et al., 2003). Therefore, the authors use different methods to predict fecundity. The fecundity varied from 2,000 to 9,000 oocytes for fish ranging in total length and body weight from $19.5 \mathrm{~cm}$ and $76.00 \mathrm{~g}$ to $32.2 \mathrm{~cm}$ and $333 \mathrm{~g}$ in the Solhan Creek. Ünlü (1991) and Türkmen et al. (2002) reported a fecundity of 3,754 to 35,859 oocytes and 4,713 to 18,240 oocytes for females, respectively, while Ekmekçi (1996) specified it from 10,840 to 12,175 oocytes in Sariyer Dam Lake. Y1ldırım and Aras (2000) reported a fecundity between 1,768 to 29,121 oocytes from the Çoruh River. Erdoğan (1998) reported similar values of fecundity 1,711 to 16,254 oocytes from the Aras River, while Türkmen et al. (2002) estimated it between 3,754 to 35,859 oocytes for females from the Karasu River. Fecundity correlates with the fish length and weight accordig to Bircan and Polat (1995), Erdoğan (1998), Yildırım and Aras (2000), and Çoban et al. (2013). A basic property of fecundity is its increase during the growth of the fish. A large fish produces more eggs than a small one. The correlation between fecundity and body weight in most fishes is higher than that between fecundity and total length (Nikolsky, 1980). Çoban et al. (2013) reported fecundity values between 1,860 and 15,624 eggs in fish ranging from 11.8 to $19.5 \mathrm{~cm}$ in length caught in the Hazar Lake. The fecundity of Capoeta umbla was strongly correlated to TL and TW, due to the high value of the determination parameter $(r 2)$ obtained from the relationships. Our study showed that the fecundity increased as the female fish grew. Larger fish with a greater visceral space for egg development have larger ovaries, and thus more eggs than smaller fish. Although variation occurs between years in response to environmental conditions (Bagenal and Braum, 1978; Mitton and Lewis, 1989), it is also generally accepted that egg size also increases with body length (Wright and Shoesmith, 1988; Zivkov and Petrova, 1993; Moyle and Cech, 2004). However, variation in fecundity between populations of the same species and between years within a population is well known (Bowering, 1978; Pinhorn, 1984; Gundersen, 1990; Kraus et al., 2002; Bitty Blanchard et al., 2003; Power et al., 2005; Rideout and Morgan, 2007). Fecundity is influenced by age, size, fish species, feeding of fish, season, and environmental conditions (Nikolsky, 1980). Differences between this study and other studies can be explained by the above-mentioned reasons.

\section{CONCLUSIONS}

The tigris scraper Capoeta umbla is an important fishery resource in the Murat River, Eastern Anatolia of Turkey, due to their high commercial value. Thus, the aim of this work was to study the reproduction to understand the population dynamics of this species for ensuring sustainable and rational exploitation of their stocks in the studied region. To achieve sustainable maximum production in the population of this species in the Murat River basin, the fishery activities should be forbidden between May and July. 


\section{REFERENCES}

1. Avşar D., 2016 - Fisheries biology and population Dynamics, Çukurova University Publications, Adana, 306. (in Turkish)

2. Bagenal T. B. and Braum E. (eds), 1978 - Eggs and early life history, in Methods for assessment of fish population in fresh waters, Blackwell Scientific, London, UK, 101-136.

3. Bănărescu P. M., 1999 - Capoeta Valenciennes, 1842, in The Freshwater Fishes of Europe, 5/1 (Cyprinidae 2), 1I: Rhodeus to Capoeta, Bănărescu P. M. (ed.), AULA-Verlag, Wiebelsheim, 383-406.

4. Bayır A., Sirkecioğlu A. N., Polat H. and Aras M., 2007 - Biochemical profile of blood serum of siraz C. c. umbla, Comperative Clinical Pathology, 16, 119-126.

5. Bircan R. and Polat N., 1995 - Altınkaya Baraj Gölü'ndeki Capoeta capoeta (Guldentstaedt, 1773) 'nın üreme mevsimi, yumurta verimi ve eşeysel olgunluk yaşı üzerine incelemeler, Proceedings of Eastern Anatolian Fisheries and Water Products, 287-306. (in Turkish)

6. Bitty Blanchard J. L., Frank K. T. and Simon J. E., 2003 - Effects of condition on fecundity and total egg production of eastern Scotian Shelf haddock, Canadian Journal of Fisheries and Aquaict Sciences, 60, 321-332.

7. Bowering W. R., 1978 - Fecundity of witch flounder (Glyptocephalus cynoglossus) from St. Pierre Bank and the Grand Bank of Newfoundland, Journal of the Fish Res Board of Canada, 35, 1199-1206.

8. Brown P., Sivakumaran K. P., Stoessel D., Giles A., Green C. and Walker T., 2003 - Carp population biology in Victoria, Report Marine and Freshwater Resources, 56, 202.

9. Çiçek T., Kaya A. and Bilici S., 2016 - A survey on scale of Capoeta umbla (Heckel, 1843) by geometric morphometric methods depend on gender, age and season variations, Turkish Journal of Aquaict Sciences, 31, 2, 96-104.

10. Çoban M. Z. and Şen D., 2011 - Capoeta umbla (Heckel. 1843) 'nın Hazar Gölü (Dicle Nehri) ve Keban Baraj Gölü (Fırat Nehri) populasyonlarının büyüme özelliklerinin karşılaştırılması, Journal of Fisheries Sciences, 5, 3, 180-195. (in Turkish)

11. Çoban M. Z., Gündüz F., Türkgülü İ., Örnekçi N. G., Yüce S., Demirol F. and Alp A., 2013 Reproductive properties of Capoeta umbla (Heckel, 1843) living in Lake Hazar (Elaziğ, Turkey), International Journal of Agricultural and Food Research, 2, 2, 8-47.

12. Das M., Dewan S. and Debnat S. C., 1989 - Studies on fecundity of Heteropneustes fossilis (Bloch) in a mini pond of Bangladesh, Journal of Agricultural Science, 16, 1-6.

13. Dewan S. and Doha S., 1979 - Spawning and fecundity of certain pond fishes, Bangladesh Journal of Agriculture, 4, 1-8.

14. Dinh Q. M., 2018 - Aspects of reproductive biology of the red goby Trypauchen vagina (Gobiidae) from the Mekong Delta, Journal of Applied Ichthyology, 34, 3-110.

15. Doha S. and Hye M. A., 1970 - Fecundity of the Padma River Hilsa ilisha (Hamilton), Pakistan Journal of Sciences, 22, 176-183.

16. Ekmekçi F. G., 1996 - Sarıyar Baraj Gölü’nde (Ankara) yaşayan Capoeta tinca (Heckel, 1843) 'nın bazı büyüme ve üreme özellikleri, Turk Journal of Zoology, 20, 117-127. (in Turkish)

17. Erdoğan O., 1998 - Aras Nehri'nde yaşayan Capoeta capoeta capoeta (Güldenstant, 1772) balığınn büyüme ve üreme özellikleri ile avlanma bölgesi suyunun bazı fiziko-kimyasal özelliklerinin araştırıması, Ph.D. Thesis, University of Atatürk, Erzurum, 101. (in Turkish)

18. Eroğlu M., Düşükcan M. and Çoban M. Z., 2018 - Özlüce Baraj Gölü’nde yaşayan Capoeta umbla (Heckel, 1843) 'nın bazı populasyon parametreleri, KSÜ Tarim ve Doğa Dergisi, 21, 2, 229-238.

19. Esmaeili H. R., Zareian H., Eagderi S. and Alwan N., 2016 - Review on the taxonomy of tigris scraper, Capoeta umbla (Heckel, 1843) and its confirmation record from the Iranian part of Tigris River, Persian Gulf basin (Teleostei: Cyprinidae), Fish Taxa, 1, 1, 35-44. 
20. Fontana A., 1979 - Etude du stock demersal cotier congolais. Biologie et dynamique des principales especes exploitées. Propositions d'amenagement de la pecherie, M.Sc. Thesis, Université Pierre et Marie Curie, Paris, France, 300.

21. Freyhof J., 2014 - Capoeta umbla, The IUCN Red List of Threatened Species: e.T19027584A19222918, DOI: org/10.2305/IUCN.UK.2014.

22. Gebrekiros S. T., 2016 - Factors affecting stream fish community composition and habitat suitability, Aquaculture and Marina Biology, 4, 2, 00076, DOI: 10.15406/jamb.2016.04.00076.

23. Grandcourt E. M., Al-Abdessalaam T. Z, Francis F., Al-Shamsi A. T. and Hartmann S. A., 2009 - Reproductive biology and implications for management of the orange-spotted grouper Epinephelus coioides in the southern Arabian Gulf, Journal of Fish Biology, 74, 820-841

24. Gundersen A. C., Hjqrleifsson B. and Kennedy E. J., 1990 - Fecundity of Greenland halibut (Reinhardtiushippoglossoides W.) in the waters of Iceland, Journal of Northwest Atlatic Fisheries Sciences, 40, 75-80.

25. Gül A., Yılmaz M. and Solak K., 1996 - Fırat Nehri Tohma suyunda yaşayan Capoeta trutta (Heckel, 1843) 'nın büyüme özellikleri, Doğa Turkish Journal of Zoology, 20, 177-185. (in Turkish)

26. Gündüz F., Demirol F., Çoban M. Z., Yüksel F., Kurtoğlu F., Yıldız N. and Kılıç A., 2015 Some population parameters of Capoeta umbla (Heckel, 1843) in Uzunçayir Dam Lake, International Journal of Pure Applied Sciences, 1, 2, 100-111.

27. Güneş M., 2007 - Determination of some bio-ecological properties and total fat a fatty acid compositions of Capoeta capoeta umbla Heckel, 1843 populations living in Tercan Dam and Tuzla River, Thesis master, Atatürk University of Atatürk. (in Turkish)

28. Helfmann G. S., Collette B. B. and Facey D. E., 1997 - The diversity of fishes, Blackwell Science, London, 529.

29. Holden M. K. and Raitt D. F. S., 1974 - Methods of resource investigation and their application, Food and Agriculture Organization of the United Nations, Fisheries Technical Paper, 1, Rome, 115.

30. Jeeva V., Kumar S., Verma D. and Rumana H. S.,2011 - River fragmentation and connectivity problems in Gange River of upper Himalayas: the effect on the fish communities (India); Transylvanian Review of Systematical and Ecological Research, 12, The Wetlands Diversity, 75-90.

31. Kara C., Alp A. and Şimșekli M., 2010 - Distribution of fish fauna on the upper and middle basin of Ceyhan River, Turkey, Turkish Journal of Fisheries and Aquatic Sciences, 10, 111-121.

32. Kar D. and Khynriam D., 2020 - On a recent pioneering taxonomic study of the fishes from rivers Diyung, Vomvadung, Khualzangvadung, Tuikoi and Mahur in Dima Hasao District of Assam (India), Transylvanian Review of Systematical and Ecological Research, 22.3, The Wetlands Diversity, 83-106.

33. Kılıç M., 2015 - Human and economic geography in Solhan (Bingöl), Ph. D. Thesis, University

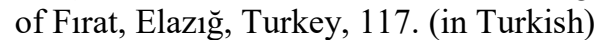

34. Khoshnood Z., 2014 - Identification and study of fish species in Karkheh River (Iran); Transylvanian Review of Systematical and Ecological Research, 16.2, The Wetlands Diversity, 97-106.

35. Komalefe O. O. and Arawomo G. A. O., 2007 - Reproductive strategy of Oreochromis niloticus (Pisces: Cichlidae) in Opa Reservoir, Ile-Ife, Nigeria, Revista De Biologia Tropical, 55, 2, 595602.

36. Kraus G., Tomkiewicz J. and Köster F. W., 2002 - Egg production of Baltic cod (Gadus morhua) in relation to variable sex ratio, maturity, and fecundity, Canadian Journal of Fisheries and Aquaict Sciences, 59, 1908-1920.

37. Miller P. J. 1984 - The tokology of gobioid fishes, in Potts G. W. and Wootton R. J. (eds), Fish reproduction: Strategies and tactics, Academic Press, London, 119-153.

38. Mitton J. B. and Lewis W. M., 1989 - Relationships between genetic variability and life-history features of bony fishes, Evolution, 43, 1712-1723. 
39. Moyle P. B. and Cech J. J, 2004 - Fishes, an introduction to ichthyology, Prentice Hall, Upper Saddle River, New Jersey, 726.

40. Muchlisin Z. A., Musman M. and Siti-Azizah M. N., 2010 - Spawning seasons of Rasbora tawarensis in Lake Laut Tawar, Aceh Province, Indonesia, Reproductive Biology and Endocrinology, 8, 49.

41. Murua H. and Saborido-Rey F., 2003 - Female reproductive strategies of marine fish species of the North Atlantic, Journal of Northwest Atlantic Fisheries Sciences, 33, 23-31.

42. Nikolsky G. V., 1980 - Theory of fish population dynamics as the biological background for rational exploitation and management of fishery resources, Otto Koeltz Science Publishers, Koengstein, 323.

43. Özdemir N., 1982 - Elazığ-Hazar gölünde bulunan Capoeta capoeta umbla'nın (Heckel, 1843) ekonomik değeri ve yetiştirilme olanaklarına ilişsin biyolojik özellikleri, Doğa Veteriner, Hayvancllık ve Ormancılık Dergisi, 6, 69-75. (in Turkish)

44. Öztürk S., 1996 - The reproductions biology of Capoeta capoeta umbla (Heckel, 1843) living in Hazar Lake, Thesis master, University of Firat, Elazı ğ, 1996, 45.

45. Pinhorn A. T., 1984 - Temporal and spatial variation in fecundity of Atlantic cod (Gadus morhua) in Newfoundland waters, Journal of NW Atlantic Fisheries Sciences, 5, 161-170.

46. Power M., Dempson J. B., Reist J. D., Schwarz C. J. and Power G., 2005 - Latitudinal variation in fecundity among Arctic char populations in eastern North America, Journal of Fish Biology, 67, 255-273.

47. Radkhah A. R. and Eagderi S., 2020 - Investigation on the global distribution of invasive fish species, convict cichlid Amatitlania nigrofasciata (Perciformes, Cichclidae) over the past years with emphasis on Iranian inland waters, Transylvanian Review of Systematical and Ecological Research, 22.3, The Wetlands Diversity, 45-56.

48. Reynaldo de la Cruz E., Cendejas M. E. V., Machado S. R., Fernández F. G. and Torres A. V., 2020 - Diversity and structure of the ichthyologic communities in the diving sites in Holguin (Cuba), Transylvanian Review of Systematical and Ecological Research, 22.3, The Wetlands Diversity, 57-82.

49. Rideout R. M. and Morgan M. J., 2007 - Major changes in fecundity and the effect on population egg production for three species of Northwest Atlantic flatfish, Journal of Fish Biology, 70, 1759-1779.

50. Rios J. M., 2021 - Predation by the nonnative raimbow trout, Oncorhynchus mykis (Walbaum, 1792), on the native biota from freshwater environment of the central Andes (Argentina), Transylvanian Review of Systematical and Ecological Research, 23.1, The Wetlands Diversity, 67-72.

51. Sarker P. K., Pal H. K., Rahman M. M. and Rahman M. M., 2002 - Observation on the fecundity and gonado-somatic index of Mystus gulio in brackish waters of Bangladesh, Journal of Biological Sciences, 2, 235-237.

52. Shafi M., Quddus M. M. A. and Rahman S., 1978 - Fecundity of Indian Halibut, Psettodes erumei (Bloch and Schneider) from the Bay of Bengal Bangladesh, Journal of Zoology, 6, 113120.

53. Sheridan A. K., 2008 - The genetic impacts of human activities on wild fish populations, Reviews in Fisheries Science, 3, 2, 91-108.

54. Sosai A. S., 2015 - Illegal fishing in southern Mannar Island coastal area (Sri Lanka), Transylvanian Review of Systematical and Ecological Research, 17.1, The Wetlands Diversity, 95-108.

55. Su G., Logez M., Xu J., Tao S., Villéger S. and Brosse S., 2021 - Human impacts on global freshwater fish biodiversity, Science, 371, 6531, 835-838, DOI: 10.1126/science.abd3369.

56. Sümbüloğlu K. and Sümbüloğlu V., 2019 - Biyoistatistik, Hatipoğlu Yayıncılık, 299. (in Turkish) 
57. Şen D., 1988 - Investigation of Kalecik, Karakoçan Pond (Elazığ) and aquculture, Doğa Türk Biyoloji Dergisi, 12, 1988, 69-85.

58. Tomkiewicz J., Morgan M. J., Burnett M. and Saborido-Rey F., 2003 - Available information for estimating reproductive potential of Northwest Atlantic groundfish stocks, Journal of Northwest Fisheries Sciences, 33, 1-21.

59. Trichkova T., Stefanov T., Vassilev M. and Zivkov M., 2009 - Fish species diversity in the rivers of the north-west Bulgaria, Transylvanian Review of Systematical and Ecological Research, 8, The Wetlands Diversity, 161-168.

60. Turan D., Kottelat M., Ekmekçi F. G. and İmamoğlu H. O., 2006 - A review of Capoeta tinca, with descriptions of two new species from Turkey (Teleostei: Cyprinidae), Revue Suisse de Zoologie, 113, 2, 421-436, DOI: 10.5962/bhl.part.80358.

61. Türkmen M., Erdoğan O., Yıldırım A. and Akyurt İ., 2002 - Reproduction tactics age and growth of C. c. umbla Heckel, 1843 from the Așkale Region of the Karasu River, Turkey, Fisheries Research, 54, 317-328.

62. Ünlü E., 1991 - Dicle Nehri'nde yapayan Capoeta trutta (Heckel, 1843) 'nin biyolojik özellikleri üzerine çalışmalar, Turkish Journal of Zoology, 15, 22-38. (in Turkish)

63. Wright R. M. and Shoesmith E. A., 1988 - The reproductive success of pike, Esox lucius: aspects of fecundity, egg density and survival, Journal of Fish Biology, 33, 623-636.

64. Yeldan H. and Avşar D., 2000 - A preliminary study on the reproduction of the rabbitfish (Siganus rivulatus (Forsskal, 1775) in the Northeastern Mediterranean, Turkish Journal of Zoology, 24, 2, 173-182.

65. Yildırım A. and Aras S., 2000 - Some reproduction characteristics of Capoeta tinca (Heckel, 1843) living in the Oltu stream of Çoruh basin, Turkish Journal of Zoology, 24, 95-101.

66. Yüce S. and Şen D., 2003 - Reproduction properties of Capoeta capoeta umbla (Heckel, 1843) living in Hazar Lake (Elazı $\breve{g}$ ), Firat Journal of Science and Technology, 15, 1, 107-116.

67. Yüksel F., 2002 - Biological characteristics in terms of fishing of Capoeta capoeta umbla (Heckel, 1843) living Hazar Lake, Firat Journal of Science and Technology, 14, 2, 193-200.

68. Yilmaz M., Gül A. and Solak K., 2003 - Growh performance of Capoeta capoeta umbla (Heckel, 1843) living in the region between Sivas and Erzincan of upper Euphrates, Gazi Journal of Education, 23, 2, 23-40.

69. Zivkov M. and Petrova G., 1993 - On the pattern of correlation between the fecundity, length, weight and age of pikeperch Stizostedion lucioperca, Journal of Fish Biology, 43, 2, 173-182. 